DOI:https://doi.org/10.37699/2308-7005.1.2020.12

В. О. Шапринський, О. О. Воровський, О. А. Камінський, A. В. Верба, А. М. Форманчук, Ю. А. Миронішен, О. І. Черніченко

Вінницький національний медичний університет ім. М. І. Пирогова

(C) Колектив авторів

\section{ЕХІНОКОКОЗ ПЕЧІНКИ: ДІАГНОСТИКА ТА ДОСВІД ХІРУРГІЧНОГО ЛІКУВАННЯ}

Реферат. Мета дослідження - проаналізувати результати лікування хворих з ехінококозом печінки.

Матеріали та методи. Проаналізовано результати лікування 76 хворих з ехінококозом печінки: жінок - 66 (86,8\%), чоловіків - $10(13,2 \%)$. Первинний ехінококоз був виявлений у $73(96,1 \%)$ хворих, вторинний - у 3 (3,9\%). Серед інструментальних методів дослідження діагностичне значення мали ультразвукове та комп'ютерно-томографічне обстеження. Поодинокі кісти печінки виявлені у $66(86,8 \%)$ хворих, множинні - у 10 (13,2\%). Серед хворих з солітарними кістами права доля печінки вражалась частіше ніж ліва - 56 $(73,7 \%)$ хворих проти 20 (26,3\%). Ускладнення ехінококозу відзначено у $16(21,1 \%)$ пацієнтів. Серед них найчастішими були: нагноєння кісти - у $13(17,1 \%)$; прорив кісти у вільну черевну порожнину - у 1 (1,3\%), у плевральну порожнину - у 1 (1,3\%), в біліарний тракт - у $1(1,3 \%)$ випадку. У $20(26,3 \%)$ хворих операцію виконували 3 верхньо-серединного доступу, у 46 $(60,5 \%)-3$ косих підреберних доступів за Кохером або за Федоровим. Періцистектомія була виконана у $52(68,4 \%)$ хворих, у 8 (10,5 \%) пацієнтів були виконані резекції сегментів печінки з ехінококовою кістою, у 4 (5,3\%) - розкриття кісти 3 видаленням вмісту й обробкою її порожнини. Лапароскопічну ехінококектомію застосували у $12(15,8 \%)$ хворих. У післяопераційному періоді у $16(21,1 \%)$ хворих виявлені ускладнення. Використання зварювального електрокоагулятора ЕК-300M «Свармед» при термічній санації стінок залишкової порожнини після ехінококектомії дозволило зменшити крововтрату $3(2200,0 \pm 210,0)$ до $(250,0 \pm 50,0)$ мл, а кількість рецидивів з 2,8 до $0,0 \%$. До і після операції проводили протирецидивну антипаразитарну терапію альбендазолом (Ворміл) у два цикли по 28 днів, розділених 14-денною перервою. Доза при масі тіла більше 60 кг становила 400 мг 2 рази/добу, а при вазі менше 60 кг препарат призначали із розрахунку 15 мг/кг/добу.

Результати та обговорення. При застосуванні лапароскопічної ехінококектомії вдалося зменшити інтраопераційну крововтрату у 9 разів $(\mathrm{p}=0,0001)$; тривалість операції - у 2 рази $(\mathrm{p}>0,05)$, перебування у стаціонарі - у 3,3 разу $(\mathrm{p}=0,002)$. Летальних випадків не було.

Висновки. Перицистектомія є ефективною операцією щодо повного одужання та не дає рецидивів захворювання. Застосування зварювального електрокоагулятора та лапароскопічна ехінококектомія суттєво покращують результати лікування хворих із паразитарними кістами печінки.

Ключові слова: печінка, ехінококоз, ехінококектомія, періцистектомія

\section{Вступ}

Ехінококове ураження печінки - це досить поширене паразитарне захворювання, яке відноситься до важких паразитарних захворювань і в своєму розвитку завжди проходить стадію формування кіст, які вражають внутрішні органи людини [1]. Збудником є личинкова стадія ціп'яка Echinococcus granulosus sensu lato (штам собак-овець) [2], який паразитує в м'ясоїдних тваринах (остаточний хазяїн) [3]. Проміжний хазяїн паразита - людинайі сільськогосподарські тварини.

Ендемічними регіонами ехінококозу є Туреччина, Молдова, деякі регіони Росії, Туркменістан, Киргизстан, Австралія, країни Середземномор'я, деякі райони Америки, Пів- 
нічної та Східної Африки [4]. Так, наприклад, за статистичними даними щорічно у Туреччині реєструється до 4000 нових випадків захворювання а у Світі хворіють на ехінококоз до 1 мільйона людей.

Територія України є осередком напруженості ехінококозу, частота якого має стійку тенденцію до збільшення. В першу чергу це пов'язано із кращою й більш точною лабораторною та інструментальною діагностикою та глобальною міграцією населення. Число хворих з цією патологією постійно зростає й коливається від 0,4 до 7,3\%. Частота рецидивів захворювання складає від 2,0 до 23,2 \% і нерідко закінчується летально [5].

Щодо клінічного перебігу ехінококозу, то він тривалий час має безсимптомний перебіг і може протікати із незначною еозинофілією, підвищеним ШЗЕ [6]. Основними ускладненнями гідативної хвороби є розрив ехінококової кісти (ЕК), з наступним розвитком вторинної інфекції, анафілаксією та дисемінованим формуванням дочірних кіст у порожнині живота. Пряме поширення на плевру, перикард, товсту кишку та кістки трапляється рідше [4].

Серед сучасних методів діагностики перевага надається імунологічним методам діагностики ехінококозу: реакція латекс-аглютинації, непряма гемаглютинація, імуноферментний аналіз (ІФА) із дослідженням різного класу антитіл Ці реакції практично не мають протипоказів, їхня діагностична чутливість лежить в межах 56,0-100,0 \% [7]. Діагностичний метод Касоні на тлі низької інформативності майже не застосовується [8].

Серед інструментальних методів діагностики на перший план виступає ультразвукове дослідження (УЗД) [5]. Порівняльний аналіз УЗД і комп'ютерної томографії (КT) надає переваги УЗД при виявленні кіст діаметром менше 1 см, але поступається вплані топічноїдіагностики [9].

Єдиним ефективним методом лікування ЕК печінки є хірургічний. Серед хірургічних методів застосовуються: екстирпація ЕК (перицистектомія), напівзакрита та закрита ехінококектомії [10]. В останні роки відзначається тенденція до розширення показань до мініінвазивних технологій (лапароскопічна ехінококектомія, технологія PAIR, видалення EK з міні-доступу) як при «складній» локалізації, так і при ускладнених ЕК. Основною небезпекою при лапароскопічній ехінококектомії є розрив EK 3 можливим розвитком анафілактичного шоку, дисемінація паразита, кровотеча. Частота післяопераційних ускладнень становить 6,0-22,0 \% випадків, летальність наближається до нуля, рецидивів практично не відзначають [1]. Вважають необхідним в комплекс лікуван- ня включити хіміотерапію альбендазолом чи празиквантелем [10].

Таким чином, на сьогодні не існує єдиної методики видалення паразита та обробки залишкової порожнини, точних показань до використання різноманітних видів операцій.

\section{Мета дослідження}

Проаналізувати результати хірургічного лікування ехінококозу печінки шляхом оптимального вибору оперативного втручання на печінці.

\section{Матеріали та методи досліджень}

У клініці хірургії № 1 Вінницького національного медичного університету ім. М. І. Пирогова, яка знаходиться на базі хірургічного відділення Вінницької обласної клінічної лікарні ім. М. I. Пирогова з 2011 по 2020 р. було прооперовано 76 хворих із ехінококозом печінки. Жінок було 66 (86,8 \%), чоловіків - 10 (13,2\%). Середній вік становив $(46,5 \pm 2,5)$ років. Первинний ехінококоз був виявлений у $73(96,1 \%)$ хворих, вторинний у $3(3,9 \%)$. Поодинокі кісти печінки виявлені у $66(86,8 \%)$ хворих, множинні - у $10(13,2 \%)$. Розміри кіст в середньому складали 4-5 см, максимальна сягала до 18 cм в діаметрі. За локалізацією права доля вражалась частіше у $56(73,7 \%)$ хворих, ніж ліва - 20 (26,3\%) випадків. У 16 (21,1\%) випадках хворі поступали 3 ускладненими формами ехінококозу: нагноєння кісти - $13(17,1 \%)$, прорив у вільну черевну порожнину - $1(1,3 \%)$, прорив в плевральну порожнину $-1(1,3 \%)$, прорив у біліарний тракт $-1(1,3 \%)$.

При фізикальному обстеженні і зборі анамнезу вдавалось виявити помірний біль в правому підребер'ї, помірну слабкість, періодичне підвищення температури тіла, висипи на шкірі, свербіж, жовтяницю. Серед інструментальних методів дослідження в обов'язковому порядку виконувались Rц легенів, УЗД, КТ. Оглядова $\mathrm{R}$-графія легень використовувалась 3 метою виключення поєднаного враження ехінококом легені, які спостерігали у 2 (2,8 \%) випадках.

Наявність ЕК була показом до оперативного лікування. У 20 (26,3 \%) випадках, при локалізації ЕК в лівій долі печінки операцію виконували 3 верхньосерединного доступу. У $46(60,5 \%)$ - косі підреберні доступи за Кохером або Федоровим.

Усім хворим, згідно протоколу лікування ЕК, проводили протирецидивну антипаразитарну терапію альбендазолом (Ворміл). Доза для пацієнтів при масі тіла понад 60 кг становила 400 мг 2 рази на добу, а при менше 60 кг препарат призначали із розрахунку 15 мг/кг/добу. Перед 
операцією та після операції проводили два цикли по 28 днів, розділені 14-добовою перервою.

Статистичну обробку результатів дослідження виконували за допомогою пакету прикладних програм «Statistica 5.5» фірми Statsoft (належить ЦНІТ ВНМУ ім. М. І. Пирогова, ліцензійний номер № AXXR910A374605FA) 3 розрахунком середнього арифметичного досліджуваного показника (М), стандартної помилки середнього (m), відносних величин (частота, \%). Середні статистичні показники наведені у вигляді $\mathrm{M} \pm \mathrm{m}$.

\section{Результати досліджень та їх обговорення}

Вибір операційного методу та доступу визначались індивідуально і залежали від локалізації, глибини розташування та розмірів ЕК. Для зручності операції і маніпуляцій при локалізації кіст в правій долі печінки ми завжди пересікали вінцеву та круглу зв'язки і, беручи останню на затискач, могли підтягувати печінку в рану. 3 метою профілактики інтраопераційного обсіменіння сколексами паразита операційне поле обкладали трьома-чотирма тампонами, змоченими бетадином. Періцистектомія була виконана у $52(68,4 \%)$ хворих, у $8(10,5 \%)$ пацієнтів були виконані резекції сегментів печінки з EK, у 4 (5,3\%) - розкриття кісти з видаленням вмісту та обробкою іiї порожнини. Лапароскопічну ехінококектомію застосували в $12(15,8 \%)$ хворих.

У $18(23,7 \%)$ випадках спостерігали зрощення кісти із сусідніми органами: шлунок, жовчний міхур, діафрагма, сальник. При їх розділенні виникала загроза порушення цілісності капсули кісти і обсіменіння сколексами органів черевної порожнини. В даних випадках проводилася пункція кісти, евакуація іï вмісту, цистотомія і видалення хітинової оболонки 3 дочірніми і онучатими бульбашками. У $8(10,5 \%)$ хворих з багатокамерною ЕК видалити вміст пункційно не вдалося через обтурацію просвіту голки обривками хітинової оболонки. У цих випадках доводилося робити цистотомію і обробляти внутрішню поверхню високочастототним зварювальним електрокоагулятором ЕК-300М «Свармед». У 16 (21,1 \%) хворих після евакуації вмісту кісти виявлялися перфорантні жовчні протоки, що відкривалися в її просвіт. При наявності жовчної протоки на витягнутій серветці зазвичай з'являлася жовта пляма. Цим же способом можна користуватися для визначення ефективності ліквідації перфорації жовчної протоки. Подальший хід оперативного втручання залежав від індивідуальних характеристик кісти. Завершити операцію без формування залишкової порожнини в печінці можливо було при виконанні субтотальної періцістектомії. Крупні венозні гілки, які під- ходили до кісти, прошивали і перев'язували ниткою або кліпували. У 4 (5,3 \%) випадках при глибокому заляганні EK, де мала місце загроза виникнення профузної кровотечі та пошкодження крупних жовчних протоків, повне видалення фіброзної капсули не виконували. В цих випадках максимально висікали капсулу та 3 метою гемостазу дефект обробляли зварювальним електрокоагулятором ЕК-300М «Свармед». У даних випадках виконували контрольний огляд за допомогою КТ.

При видаленні поодиноких ЕК крововтрата не перевищувала 200,0-300,0 мл. При видаленні численних ЕК (у двох хворих було аж по 5 EK), в тому числі з важкодоступних місць (VII та VIII сегменти печінки), крововтрата інколи досягала до 2,5 л крові.

Лапароскопічну ехінококектомію виконували із локалізацією ЕК в II, III, IV, V, VI. Не застосовували її при дисемінованому ехінококозі печінки та при локалізації ЕK в I, VII та у VIII сегментах. Використання лапароскопічних оперативних втручань при ехінококозі печінки дозволило зменшити інтраопераційну крововтрату в 9 разів $(\mathrm{p}=0,0001)$; тривалість операції - від $(3,5 \pm 0,3)$ до $(1,5 \pm 0,1)$ години (у 2 рази) ( $>0,05)$, перебування в стаціонарі від $(10 \pm 2,0)$ до $(3 \pm 1,0)$ діб (у 3,3 разу) $(p=0,002)$; рецидиви мали місце у $2(2,6 \%)$ випадках при лапаротомному доступі.

У післяопераційному періоді у 1 (1,3 \%) хворого спостерігали кровотечу, яку зупинили зварювальним електрокоагулятором EK-300M «Свармед» та додатковим прошиванням ранової поверхні печінки. Використання даного методу дало змогу зменшити крововтрату $3(2200,0 \pm 210,0)$ до $(250,0 \pm 50,0)$ мл, незначне жовчопідтікання відмічено тільки у 7 (9,2 \%) хворих. У 6 (7,9 \%) пацієнтів відмічений правобічний ексудативний плеврит, який розрішився консервативно. Рецидивів захворювання ми не мали після радикальних оперативних втручань (перицистектомія, резекція сегменту з кістою). Рецидив після паліативних операцій відмічено у 2 хворих (2,63 \%). Летальних наслідків після виконання даних втручань ми не мали.

Таким чином, клінічний перебіг ехінококозу тривалий час мав безсимптомний перебіг, внаслідок чого $16(21,1 \%)$ пацієнтів госпіталізовані 3 ускладненими формами ехінококозу (нагноєння кісти, прорив у вільну черевну порожнину, прорив в плевральну порожнину, прорив у біліарний тракт); у 18 хворих $(23,7 \%)-$ мали місце зрощення кісти із сусідніми органами (шлунок, жовчний міхур, діафрагма, сальник); у 16 (21,1\%) - в просвіт ЕК відкривалися жовчні нориці. Саме у цих пацієнтів, при надходженні, були скарги на біль в правому підребер'ї, періодичне підвищення температу- 
ри тіла, висипи на шкірі, свербіж, жовтяницю. В діагностиці ЕК основним було УЗД, КТ, які виконували з метою виявлення дочірніх й онучатих кіст та визначення об'єму операції, МРТ дослідження застосовували у хворих із ускладненою ЕК. Саме цим $52(68,4$ \%) хворим вдалось виконати періцистектомію, де, завдяки, застосуванню зварювального електрокоагулятора ЕК-300М «Свармед» вдалося радикально забрати капсулу ЕК, добитись стійкого гемостазу та попередити жовчопідтікання. 12 (15,8 \%) хворим, 3 неускладненими формами ЕК вдалось провести лапароскопічну ехінококектомію без ушкодження капсули.

\section{Висновки}

1. Ехінококектомія з повним висіченням фіброзної капсули печінки -перицистектомія, $є$ радикальною й ефективною операцією щодо повного одужання та не дає рецидивів захворювання.

2. Застосування зварювального електрокоагулятора EK-300M «Свармед» при термічній санації стінок залишкової порожнини після ехінококектомії дало змогу зменшити крововтрату $3(2200,0 \pm 210,0)$ мл до $(250,0 \pm 50,0)$ мл $(\mathrm{p}=0,0001)$, а кількість рецидивів - 32,8 до $0,0 \%$ та практично уникнути жовчопідтікання.

3. Лапароскопічну ехінококектомію доцільно застосовувати при доступних чітко видимих (II-VI) сегментах печінки. При лапароскопічниій ехінококектомії вдалось зменшити інтраопераційну крововтрату в 9 разів $(\mathrm{p}=0,0001)$; тривалість операції - у 2 рази $(\mathrm{p}>0,05)$, скоротити перебування в стаціонарі - у 3,3 разу $(\mathrm{p}=0,002)$.

\section{ПЕРЕЛІК ПОСИЛАНЬ}

1. Киртанасов ЯП., Ившин ВГ. Чрескожные вмешательства в лечении больных многокамерным гидатидным эхинококкозом печени. Вестник новых медицинских технологий. Электронное издание. 2019;13(2):23-32. DOI: https://doi.org/10.24411/2075-4094-2019-16365.

2. Paternoster G, et al. Epidemic cystic and alveolar echinococcosis in Kyrgyzstan: an analysis of national surveillance data. The Lancet Global Health. 2020;8(4):603-11. DOI: https://doi.org/10.1016/s2214-109x(20)30038-3;

3. Tetali B, Grahf DC, Abou Asala ED, Axelson D. An Atypical Presentation of Cystic Echinococcosis. Clinical Practice and Cases in Emergency Medicine. 2020:1-3. DOI: https://doi.org/10.5811/cpcem.2020.1.45842.

4. Ito A, Nakao M, Lavikainen A, Hoberg E. Cystic echinococcosis: Future perspectives of molecular epidemiology. Acta tropica.2017;165:3-9. DOI: https://doi.org/10.1016/j. actatropica.2016.05.013.

5. Ветшев ПС, Мусаев ГХ, Фатьянова АС. Эхинококкоз: основы диагностики и роль миниинвазивных технологий (обзор литературы). Анналы хирургической гепатологии. 2018;20(3):47-53. DOI: https://doi. org/10.16931/1995-5464.2015347-53.

6. Шамсиев АМ, Шамсиев ЖА, Курбаниязитов ЗБ, Рахманов КЭ, Давлатов СС. Эхинококкоз печени: частота встречаемости, патогенез, класификация, диагностика и лечение (обзор литературы). Клінічна та експериментальна патологія. 2018;3(65):126-33. DOI: https://doi. org/10.24061/1727-4338.XVII.3.65.2018.145.

7. Калмыков ЕЛ, Гулов МК, Капустин ББ, Мухаббатов ДК, Нематзода О, Зардаков СМ, Кадыров АР. К вопросу о мини-инвазивной хирургии эхинококкоза печени. Новости хирургии. 2019;27(5):563-73. DOI: https://doi.org/10.18484/2305-0047.2019.5.563;

8. Бодня ЕИ, Велиева ТА, Бодня ИП. Оптимизация диагностического алгоритма у больных эхинококкозом печени. Гепатологія. 2018;4:20-37. URL: file://D: / users/user/Downloads/gepat_2018_4_5\%20(2).pdf;

9. Axrorovich SU, Israfulovich $\mathrm{MZ}$, Isomiddinovich RM, Yakhshiboevich SZ. Surgical tactics in liver echinococcosis of subphrenic localization. European science review. 2018:212-13. URL: file://D:/users/user/Downloads/surgical-tactics-in-liver-echinococcosis-of-subphrenic-localization.pdf;

10.Bayrak M, Altintas Y. Current approaches in the surgical treatment of liver hydatid disease: single center experience. BMC Surg. 2019; 95:1054. DOI: https://doi.org/10.1186/ s12893-019-0553-1.

\section{REFERENCES}

1. Kirtanasov IP, Ivshin VG. [Percutaneous interventions in the treatment of patients with multichamber hydatid echinococcosis of the liver]. Vestnik novykh meditsinskikh tekhnologiy. Elektronnoye izdaniye. 2019;13(2):23-32. Russian. doi: https://doi.org/10.18484/2305-0047.2019.5.563

2. Paternoster G, Boo G, Wang C, et al. Epidemic cystic and alveolar echinococcosis in Kyrgyzstan: an analysis of national surveillance data. The Lancet Global Health. 2020;8(4):e603-e611. doi: https://doi.org/10.1016/s2214$109 x(20) 30038-3$

3. Tetali B, Grahf DC, Abou Asala ED, Axelson D. An Atypical Presentation of Cystic Echinococcosis. Clinical Practice and Cases in Emergency Medicine. 2020:1-3. doi: https://doi.org/10.5811/cpcem.2020.1.45842
4. Ito A, Nakao M, Lavikainen A, Hoberg E. Cystic echinococcosis: Future perspectives of molecular epidemiology. Acta tropica. 2017;165:3-9. doi: https://doi.org/10.1016/j. actatropica.2016.05.013

5. Vetshev PS, Musaev GKh, Fatyanova AS. [Echinococcosis: the basics of diagnosis and the role of minimally invasive technologies (literature review)]. Annaly khirurgicheskoy gepatologii. 2018;20(3):47-53. doi: https://doi. org/10.16931/1995-5464.2015347-53

6. Shamsiev AM, Shamsiev JA, Kurbaniyazitov ZB, Rakhmanov KE, Davlatov SS. [Echinococcosis of the liver: frequency of occurrence, pathogenesis, classification, diagnosis and treatment (literature review)]. Klнnнchna ta yeksperimental'na patologнуа. 2018;17;3(65):126- 
133. Russian. doi: https://doi.org/10.24061/1727-4338. XVII.3.65.2018.145

7. Kalmykov EL, Gulov MK, Kapustin BB, Mukhabbatov DK, Ne»matzoda O, Zardakov SM, Kadyrov AR. [To the question of mini-invasive surgery of liver echinococcosis]. Novosti khirurgii. 2019;27(5):563-573. Russian. doi: https://doi.org/10.18484/2305-0047.2019.5.563

8. Bodnya EI. [Optimization of the diagnostic algorithm in patients with liver echinococcosis]. Gepatologhya. 2018;4:20-37. Russian. Available from: file:///D: /users/ user/Downloads/gepat _2018_4_5\%20(2).pdf
9. Axrorovich SU, Israfulovich RM, Isomiddinovich M, Yakhshiboevich SZ. Surgical tactics in liver echinococcosis of subphrenic localization. European science review. 2018:212-213. Available from: file:///D:/users/user/Downloads/surgical-tactics-in-liver-echinococcosis-of-subphrenic-localization.pdf;

10. Bayrak M., Altintas Y. Current approaches in the surgical treatment of liver hydatid disease: single center experience. BMC Surg. 2019. Vol. 95. P. 1054. DOI: https://doi. org/10.1186/s12893-019-0553-1.
ЭХИНОКОККОЗ ПЕЧЕНИ: ДИАГНОСТИКА И ОПЫТ ХИРУРГИЧЕСКОГО

ЛЕЧЕНИЯ
В. О. Шапринский,
О. О. Воровский,
О. А. Каминский,
А. В. Верба, А. Н. Форманчук,
Ю. А. Мыронишен,
А. И. Черниченко

Реферат. Цель исследования - проанализировать результаты лечения больных с эхинококкозом печени.

Материалы и методы. Проанализированы результаты лечения 76 больных с эхинококкозом печени, женщин - 66 (86,8 \%), мужчин - 10 (13,2\%). Первичный эхинококкоз был обнаружен у $73(96,1 \%)$ больных, вторичный - у 3 (3,9\%). Среди инструментальных методов исследования диагностическое значение имели ультразвуковое и компьютерно-томографическое обследование. Одиночные кисты печени обнаружены у 66 (86,8 \%) больных, множественные - у 10 (13,2\%). Среди больных с солитарными кистами правая доля поражалась чаще - у 56 $(73,7 \%)$ больных, чем левая - 20 (26,3 \%) случаев. Осложнения эхинококкоза отмечены у $16(21,1 \%)$ пациентов. Среди них чаще всего были нагноение кисты - в 13 (17,1\%); прорывы кисты в свободную брюшную полость - в $1(1,3 \%)$, в плевральную полость - в $1(1,3 \%)$, в билиарный тракт - в $1(1,3 \%)$ случае. В 20 (26,3\%) случаях операцию выполняли из верхнего срединного доступа, в $46(60,5 \%)-$ из косых подреберных доступов по Кохеру или по Федорову. Перицистектомия была выполнена у $52(68,4 \%)$ больных, у $8(10,5 \%)$ пациентов были выполнены резекции сегментов печени с эхинококкоковой кистой, у 4 (5,3\%) - раскрытие кисты с удалением содержимого и обработкой ее полости. Лапароскопическую эхинококектомию применили у $12(15,8 \%)$ больных. В послеоперационном периоде у $16(21,1 \%)$ больных наблюдались осложнения. Использование сварочного электрокоагулятора ЭК-300М «Свармед» при термической санации стенок остаточной полости после ехинококектомии позволило уменьшить кровопотерю с $(2200,0 \pm 210,0)$ до $(250,0 \pm 50,0)$ мл, а количество рецидивов - 3 2,8 до $0,0 \%$. До и после операции проводили противорецидивную антипаразитарную терапию альбендазолом (Вормил) в два цикла по 28 дней, разделенных 14-дневным перерывом. Доза при массе тела более 60 кг составляла 400,0 мг 2 раза в сутки, а при менее 60 кг препарат назначали из расчета 15,0 мг/кг/ сут.

Результаты и их обсуждение: при применении лапароскопической эхинококектомии удалось уменьшить интраоперационную кровопотерю в 9 раз ( $\mathrm{p}=0,0001)$; продолжительность операции - в 2 раза ( $>0,05)$, пребывание в стационаре - в 3,3 раза $(\mathrm{p}=0,002)$. Летальных исходов не было.

Bыводы. Перицистектомия является эффективной операцией для полного выздоровления и не дает рецидивов заболевания. Применение сварочного электрокоагулятора и лапароскопическая эхинококектомия существенно улучшают результаты лечения больных с паразитарными кистами печени.

Ключевые слова: печень, эхинококкоз, эхинококэктомия, перицистектомия 
LIVER ECHINOCOCCOSIS:

\title{
DIAGNOSIS AND
}

SURGICAL TREATMENT

EXPERIENCE

\author{
V. A. Shaprinsky, \\ O. O. Vorovsky, \\ O. O. Kamins'kyy, A. V. Verba, \\ A. M. Formanchuk, \\ Yu. A. Mironishen, \\ A. I. Chernichenko
}

Summary. The purpose: to analyze the results of treatment of patients with liver echinococcosis.

Materials and methods: results of treatment of 76 patients with echinococcosis of the liver were analyzed, women - 66 (86,8\%), men $-10(13,2 \%)$. Primary echinococcosis was detected in $73(96,1$ $\%)$ patients, secondary - in $3(3,9 \%)$. Among instrumental research methods, ultrasound and computed tomography examination were of diagnostic value. Single liver cysts were found in $66(86,8 \%)$ patients, multiple - in $10(13,2 \%)$. Among patients with solitary cysts, the right lobe was more often affected in $56(73,7 \%)$ patients than the left $-20(26,3 \%)$ cases. Echinococcosis complications were observed in $16(21,1 \%)$ patients. Among them, most often there were suppurations of the cyst - in $13(17,1 \%)$; a break of the cyst in the free abdominal cavity - in $1(1,3 \%)$, in the pleural cavity - 1 $(1,3 \%)$, in the biliary tract - in $1(1,3 \%)$. In $20(26,3 \%)$ cases, the operation was performed from the upper median access, in 46 $(60,5 \%)$ - from oblique hypochondriac accesses by Kocher or by Fedorov. Pericystectomy was performed in $52(68,4 \%)$ patients, in 8 $(10,5 \%)$ patients had resections of liver segments with an echinococcal cyst, in $4(5,3 \%)$ - cyst opening with removal of contents and treatment of its cavity. Laparoscopic echinococectomy was used in $12(15,8 \%)$ patients. In the postoperative period, complications were observed in $16(21,1 \%)$ patients. The use of the welding electrocoagulator EK-300M «Swarmed» in the thermal rehabilitation of the walls of the residual cavity after echinococectomy allowed to reduce blood loss from $(2200 \pm 210)$ to $(250 \pm 50) \mathrm{ml}$, recurrences - with 2,8 up to $0 \%$. Before and after operation was performed antirecedive antiparasitic therapy with albendazole (Vormil) in two cycles of 28 days, separated by a 14-day break. The dose at body weight over $60 \mathrm{~kg}$ was $400 \mathrm{mg} 2$ times a day, and for less than $60 \mathrm{~kg}$ the drug was prescribed at a rate of $15 \mathrm{mg} / \mathrm{kg} / \mathrm{day}$.

Results. With the use of laparoscopic echinococectomy, intraoperative blood loss was reduced by 9 times $(p=0,0001)$; duration of operation -2 times $(p>0,05)$, stay in hospital $-3,3$ times $(p=0,002)$. There were no fatal outcomes.

Conclusions. Pericystectomy is an effective operation for complete recovery and does not give recurrence of the disease. The use of a welding electrocoagulator and laparoscopic echinococectomy significantly improve the results of treatment of patients with parasitic liver cysts.

Key words: liver, echinococcosis, echinococcectomy, pericystectomy 